Reis, M. S., R. Conte, R. O. Nodari, A. C. FAntini, A. Reis, A. Mantovani and A. Mariot (2000b): Manejo sustentável do palmiteiro. Sellowia 49-52: 202-224.

Reis, M. S., M. P. GuerRA and R. O. NodARI (1998): Management of natural populations and maintenance of genetic diversity, pp. 145-156. In: Recent advances in biotechnology for tree conservation and management. IFS Proceedings, Stockolm.

Sebbenn, A. M., C. E. S. Seoane, P. Y. Kageyama and R. Vencovsky (2000): Efeitos do manejo na estrutura genética de populações de caixeta (Tabebuia cassinoides). Scientia Forestalis 58: 127-143.

Swofford, D. L. and R. B. Selander (1989): Biosys-1: A computer program for the analysis of allelic variation in population genetics and biochemical systematics. Natural History Survey, Illinois.
VENCOVsKY, R. (1997): Biometrical approaches for molecular markers: estimation of effective population size, $2 p$. In: International Workshop on Agricultural Biotechnology, Proceedings ESALQ-USP, Piracicaba, Cook College - New Jersey Agricultural Experiment Station, The State University of New Jersey.

Vergeer, P., R. Rengelink, A. Copal and J. Ouborg (2003): The interacting effects of genetic variation, habitat quality and population size on performance of Succisa pratensis. Journal of Ecology 91: 18-26.

White, G. M., D. H. Boshier and W. Powell (1999): Genetic variation within a fragmented population of Swietenia humilis Zucc. Molecular Ecology 8: 1899-1909.

Wright, S. (1931): Evolution in Mendelian populations. Genetics 16: 97-159.

\title{
Performance of Acacia senegal (L.) Willd Provenances in Dryland Savannah of Niger
}

\author{
By M. LARWANou ${ }^{\left.1,{ }^{*}\right)}$, A. RAEBILD ${ }^{2,3)}$, R. Issa ${ }^{1)}$ and E. D. KJÆR ${ }^{2)}$
}

(Received 24 ${ }^{\text {th }}$ March 2009)

\begin{abstract}
A study was conducted to evaluate the performance of 11 Acacia senegal provenances in Niger, West Africa, grown on 2 different soil types. Among the provenances, 6 are from Niger, 4 from Mali and 1 from Sudan. The assessment was carried out with measurements of growth parameters (survival rate, height, diameter and basal area) as well as gum and fruit production at age 15.

The results showed significant differences in growth parameters between soil types and provenances. The provenances from Mali perform best, followed by the local Niger provenances. There were no significant dif-

\footnotetext{
1) Université Abdou Moumouni, Faculté d'Agronomie, Niamey, Niger.

2) University of Copenhagen, Centre for Forest, Landscape and Planning, Hørsholm Kongevej 11, DK-2970 Hørsholm, Denmark.

${ }^{3}$ ) Corresponding author: Phone +45 35331619, Fax +45 35331517. E-Mail: are@life.ku.dk

*) Present address: African Forest Forum, c/o World Agroforestry Center (ICRAF), United Nations Avenue, P.O. Box 3067700100, Nairobi, Kenya.
}

ferences in gum and fruit production between provenances, but it cannot be excluded that this was a result of limited power in the test of provenance variation in these traits. Survival of the provenances was correlated to the precipitation and the latitude of the origin, whereas basal area was correlated to latitude, and height was correlated to longitude/altitude at the origin.

Recommendations could be made for genetic selection of two Mali provenances if growth is a desired character. We conclude that recommendations in terms of gum and fruit production must be based on a relative high number of sample trees as tree to tree variation within provenances may be large.

Key words: Acacia senegal, gum arabic, growth, Niger, Provenance trial, clines.

\section{Introduction}

In many African countries, Acacia senegal (L.) Willd. (Mimosaceae) plays an important role in poverty reduction. In dryland Africa, the species is used by rural people for ecological, economic, social and even cultural purposes. A. senegal is known as gum Arabic, and the tree produces gum which is used for food, medicine and in ceremonies. The gum is sold and procures revenues that 
are important for rural producers and can be seen even in the gross national product of the Sahelian countries. Other species produce gum, but gum from $A$. senegal is usually regarded as having the best quality and has various uses in cosmetic, medicinal and food industries (ARBONNIER, 2002; VON MAYDELL, 1986). The firewood of A. senegal is of high quality and is considered the best in Mauritius and Senegal with an energy value of ca 3,500 $\mathrm{kcal} / \mathrm{kg}$. A nitrogen-fixing species, it can also be used to re-establish vegetation cover in degraded areas, as well as for sand-dune fixation and wind-erosion control (NATiONAl ACADEMy of SCIENCES, 1983).

A. senegal has a wide distribution in Africa, from Senegal in the west across the Sahel to Ethiopia and Somalia, and through Eastern Africa down to Natal (voN MAYDELL, 1986). It is also found in India and Pakistan. Most of the gum comes from "the gum belt", stretching from Senegal to Sudan, and here the species is found in dry climates with precipitation ranging from 150-200 to $800 \mathrm{~mm}$ (FAGG and AlLISON, 2004). In the drier parts of its area of distribution, it tends to be restricted to sandy habitats and dry river beds, but under the higher rainfall of the south Sahelian and north Sudanian ecozones it is also found on fine structured soils (COSSALTER, 1991; WiCKENs et al., 1995).

During the 1970'ies, Niger was among the large producers of gum, and the annual export reached values above 2,500 tons. The export declined considerably during the following years, and in 2000 the official statistics in France, Nigeria and Côte d'Ivoire (the major buyers of gum from Niger) showed an export of only 115 tons. To this should be added an estimated informal export to Nigeria of ca. 1,000 tons. The decrease in export was attributed to droughts, decimating the tree populations, poor regeneration of the stands and poor organisation of the trade (REPUBLIQUE DU NiGER, 2003). Lately, due to the recent crises in Sudan, the world's largest producer of gum Arabic, there has been an increased interest in promoting the species for gum production and restoration of vegetation.

Because of its wide distribution across different environmental conditions, a series of provenances trials was established in order to find the best provenances in terms of adaptability and gum production (RAEBILD et al., 2003a,c,d). Most of these trials were evaluated at a relatively young age. The aim of this paper is to present the results of an assessment of a trial in Niger at a mature age, comprising 11 provenances from Niger, Mali and Sudan. The trial was conducted in the dry savannah zone of the country (LARWANOU, 2005).

\section{Materials and Methods}

\section{Experimental site}

The experiment was conducted at N'Dounga Forestry Research station situated $30 \mathrm{~km}$ South-West of Niamey $\left(2^{\circ} 18^{\prime} 28^{\prime}\right.$ E, $\left.13^{\circ} 15^{\prime} 00^{\prime \prime} \mathrm{N}\right)$. The mean annual precipitation at the station is around $500 \mathrm{~mm}$, with a long dry season from October to May. The mean annual temperature is approximately $28^{\circ} \mathrm{C}$. The natural vegetation type in the area is dry savannah with shrubby trees, dominated by Guiera senegalensis J.F. Gmel., Piliostigma reticulatum (DC.) Hochst. and Faidherbia albida (Del.) Chev. (LARWANOU, 2005). The soil is sandy and low in $\mathrm{N}$, with characteristics given in Table 1. Two samples were taken in the part of the trial with higher relief, and one sample taken in a part with low relief. Since there were no apparent differences between the samples, values were averaged across the three samples. The content of organic matter was $0.34 \%$, and $\mathrm{pH}\left(\mathrm{H}_{2} \mathrm{O}\right)$ was 5.3 and $\mathrm{pH}(\mathrm{KCl})$ was 4.2 .

\section{Plant material and trial establishment}

Trees from eleven seedlots of $A$. senegal were established in a field trial in 1987 with 6 from Niger, 4 from Mali and one from Southern Kordofan in Sudan. For

Table 1. - Soil properties for the trial, taken from $0-30 \mathrm{~cm}$ depth. Values are means \pm standard deviation. $\mathrm{n}=3$.

\begin{tabular}{|c|c|c|c|}
\hline \multicolumn{2}{|c|}{$\begin{array}{ll}\text { Texture }(\mathrm{mm}) & \text { Proportion } \\
& (\%)\end{array}$} & \multicolumn{2}{|c|}{ Chemical properties } \\
\hline$<0.002$ (Clay) & $8 \pm 1$ & $N(\%)$ & $0.011 \pm 0.002$ \\
\hline $0.05-0.002$ (Silt) & $6 \pm 2$ & $\mathrm{P}(\mathrm{ppm})$ & $2.7 \pm 1.5$ \\
\hline $0.25-0.10$ (Fine & $56 \pm 2$ & $\mathrm{~K}($ meq. $/ 100 \mathrm{~g})$ & $0.14 \pm 0.0 .11$ \\
\hline \multicolumn{4}{|l|}{ sand) } \\
\hline $1.00-0.50$ (Coarse & $30 \pm 1$ & $\mathrm{Na}($ meq. $/ 100 \mathrm{~g})$ & $0.037 \pm 0.005$ \\
\hline
\end{tabular}

sand)

$\mathrm{Mg}$ (meq./100 g) $\quad 0.43 \pm 0.15$

Conductivity, $\boldsymbol{\mu S} \quad 0.026 \pm 0.012 \quad \mathrm{Ca}(\mathrm{meq} / 100 \mathrm{~g}) \quad 1.4 \pm 0.3$ 
local provenances, seeds were collected by the Department of Forestry of the National Institute for Agricultural Research of Niger (INRAN). The seedlots from Mali and Sudan were obtained through CTFT and Danida Forest Seed Centre. Within Niger, the provenances range from the Northern to the Southern limit of the species. The rainfall of the provenance origins varied from 320 to $680 \mathrm{~mm}$ (Table 2).

Seeds were sown in the nursery in February and transplanted to the field during 3 days from July 19 to 21,1987 . Before planting, the soil was ploughed to avoid competition with weedy plants. The spacing was $5 \mathrm{~m} \times 5 \mathrm{~m}$.

\section{Experimental design}

The trial was designed as a randomised block design with 4 replications. Each repetition of the provenance was composed of a plot with 49 plants planted in a square of $7 \times 7$ plants in order to reduce the effect of competition between trees from different provenances. However, even though the terrain is flat, small differences in relief meant that there were apparent differences in vegetation, probably because parts of the site with a lower relief ("bas-fonds") were flooded during rain events. Therefore, three of the replications were each divided in two parts in order to create homogeneous conditions within the blocks. The data were therefore analysed as four repetitions of the 11 provenances distributed in an unbalanced design with seven blocks.

\section{Parameters measured}

The assessment was carried out in 2001, 15 years after the establishment. The parameters assessed were: survival, vertical height, diameter at $1.3 \mathrm{~m}$ and crown diameter (determined by two perpendicular measurements from the rim of the crown to the opposite rim of the crown). Basal area was calculated as $\pi \times$ (diameter $/ 2)^{2}$. On 87 trees, selected to cover different diameter classes and provenances, gum production was evaluated during the month of November 2001. At approximately $1.3 \mathrm{~m}$ above the ground, a piece of bark was removed from the trunk with a knife, and gum was collected after 3 weeks and weighed. Similarly, 99 trees were selected, and the fruits were harvested at maturity in December of the same year. Total fruit and grain weights were measured.

\section{Data analysis}

Before analysis, plot values of survival rate, mean height, basal area per ha, mean crown diameter, mean gum production and mean fruit and seed weight were calculated. All variables were analysed using a General Linear Models approach according to the model

$$
Y_{i j}=\mu+P_{i}+Z_{j}+B_{k}\left(Z_{j}\right)+\varepsilon_{i j k}
$$

Where $P_{i}$ is the effect of provenance $\left(N\left(0, \sigma_{\text {prov }}{ }^{2}\right)\right), Z_{j}$ is the fixed effect of inundation zone $j, B_{k}\left(Z_{j}\right)$ is the random effect of block $k$ nested within inundation zone, and $\varepsilon_{i j k}$ is the residual assumed to be independent $N\left(0, \sigma_{\mathrm{e}}{ }^{2}\right)$. Tests were performed in PROC GLM (SAS ${ }^{\circledR}$ Institute Inc., Cary, NC) using the RANDOM statement with the option TEST to obtain the Satterthwaite approximation for the calculation of degrees of freedom.

Residuals were analysed by plots of standardised residuals against predicted values, blocks and provenances, and normality was checked graphically and by

Table 2. - Provenances tested at N'Dounga forestry research station.

\begin{tabular}{llllll}
\hline Origin & Country & Latitude & Longitude & $\begin{array}{c}\text { Altitude } \\
\text { (m) }\end{array}$ & $\begin{array}{l}\text { Precipitation } \\
\left(\mathrm{mm} \mathrm{y}^{-1}\right)\end{array}$ \\
\hline Kadiel & Mali & $15^{\circ} 20^{\prime} \mathrm{N}$ & $9^{\circ} 27^{\prime} \mathrm{W}$ & 100 & 490 \\
Tandjé & Mali & $15^{\circ} 08^{\prime} \mathrm{N}$ & $7^{\circ} 10^{\prime} \mathrm{W}$ & 270 & 450 \\
Dialaka & Mali & $14^{\circ} 37^{\prime} \mathrm{N}$ & $10^{\circ} 22^{\prime} \mathrm{W}$ & 150 & 650 \\
Aïté & Mali & $14^{\circ} 57^{\prime} \mathrm{N}$ & $11^{\circ} 35^{\prime} \mathrm{W}$ & 100 & 560 \\
Yatawa & Niger & $13^{\circ} 40^{\prime} 31^{\prime \prime} \mathrm{N}$ & $7^{\circ} 56^{\prime} 49^{\prime \prime} \mathrm{E}$ & 264 & 600 \\
Karofane & Niger & $14^{\circ} 18^{\prime} 47^{\prime \prime} \mathrm{N}$ & $6^{\circ} 9^{\prime} 19^{\prime \prime} \mathrm{E}$ & 302 & 450 \\
Azaye & Niger & $15^{\circ} 27^{\prime} 8^{\prime \prime} \mathrm{N}$ & $6^{\circ} 16^{\prime} 42^{\prime \prime} \mathrm{E}$ & 321 & 350 \\
Goudoumaria & Niger & $13^{\circ} 42^{\prime} 40^{\prime \prime} \mathrm{N}$ & $11^{\circ} 11^{\prime} 25^{\prime \prime} \mathrm{E}$ & 351 & 340 \\
Chétimari & Niger & $13^{\circ} 11^{\prime} 10^{\prime \prime} \mathrm{N}$ & $12^{\circ} 25^{\prime} 20^{\prime \prime} \mathrm{E}$ & 382 & 320 \\
Garin Noudé & Niger & $14^{\circ} 19^{\prime} 58^{\prime \prime} \mathrm{N}$ & $8^{\circ} 16^{\prime} 1{ }^{\prime \prime} \mathrm{E}$ & 278 & 450 \\
Fallatu forest & Sudan & $13^{\circ} 10^{\prime} \mathrm{N}$ & $30^{\circ} 14^{\prime} \mathrm{E}$ & 570 & 365 \\
\hline & & & & & \\
\hline
\end{tabular}


standard tests. In the case of survival, the provenance Chétimari had an outlier, which had a large influence on the results and was not included for the purpose of testing differences between provenances in this specific character. However, the outlier was included in calcula- tion of the mean value of provenances in terms of average survival. For all other characters we estimated the least square means to present provenance performance in order to correct for the effects of the unbalance across blocks.

Table 3. - Results of analyses of variance for A. senegal.

\begin{tabular}{|c|c|c|c|c|c|c|}
\hline Source & $d f$ & $M S$ & $F$ & $P$ & $\begin{array}{l}\text { Var Com } \\
\left(\sigma_{\mathrm{prov}}{ }^{2}\right)\end{array}$ & $\begin{array}{l}\text { CVar } \\
(\%)\end{array}$ \\
\hline \multicolumn{7}{|l|}{ Survival rate } \\
\hline Provenance & $10 ; 26$ & 0.052 & 4.4 & 0.0011 & $0.105^{2}$ & 13.0 \\
\hline Inondation & $1 ; 5.3$ & 0.055 & 1.1 & 0.3315 & & \\
\hline Inondation $\times$ Block & $5 ; 26$ & 0.053 & 4.5 & 0.0043 & & \\
\hline \multicolumn{7}{|l|}{ Height } \\
\hline Provenance & $10 ; 27$ & 10347 & 8.6 & $<0.0001$ & $49.7^{2}$ & 12.8 \\
\hline Inondation & $1 ; 6.9$ & 35254 & 34.9 & 0.0006 & & \\
\hline Inondation $\times$ Block & $5 ; 27$ & 981 & 0.82 & 0.5489 & & \\
\hline \multicolumn{7}{|l|}{ Basal area per ha } \\
\hline Provenance & $10 ; 27$ & 4.15 & 2.8 & 0.02 & $0.851^{2}$ & 19.5 \\
\hline Inondation & $1 ; 15.3$ & 9.01 & 22.6 & 0.0002 & & \\
\hline Inondation $\times$ Block & $5 ; 27$ & 0.24 & 0.17 & 0.97 & & \\
\hline \multicolumn{7}{|l|}{ Crown diameter } \\
\hline Provenance & $10 ; 27$ & 1488 & 1.3 & 0.29 & $9.3^{2}$ & 2.0 \\
\hline Inondation & $1 ; 6.3$ & 6917 & 5.3 & 0.06 & & \\
\hline Inondation $\times$ Block & $5 ; 27$ & 1330 & 1.1 & 0.36 & & \\
\hline \multicolumn{7}{|l|}{ Gum production } \\
\hline Provenance & $10 ; 12$ & 1081 & 0.6 & 0.77 & 0 & 0 \\
\hline Inondation & $1 ; 7.8$ & 1.4 & 0.0 & 0.98 & & \\
\hline Inondation $\times$ Block & $5 ; 12$ & 2534 & 1.5 & 0.27 & & \\
\hline \multicolumn{7}{|l|}{ Fruits } \\
\hline Provenance & $10 ; 14$ & 182842 & 0.72 & 0.70 & 0 & 0 \\
\hline Inondation & $1 ; 16.5$ & 89672 & 0.43 & 0.52 & & \\
\hline Inondation $\times$ Block & $5 ; 14$ & 170560 & 0.67 & 0.65 & & \\
\hline \multicolumn{7}{|l|}{ Seed } \\
\hline Provenance & $10 ; 14$ & 22860 & 0.72 & 0.70 & 0 & 0 \\
\hline Inondation & $1 ; 15.6$ & 10586 & 0.37 & 0.55 & & \\
\hline Inondation $\times$ Block & $5 ; 14$ & 25017 & 0.78 & 0.56 & & \\
\hline
\end{tabular}



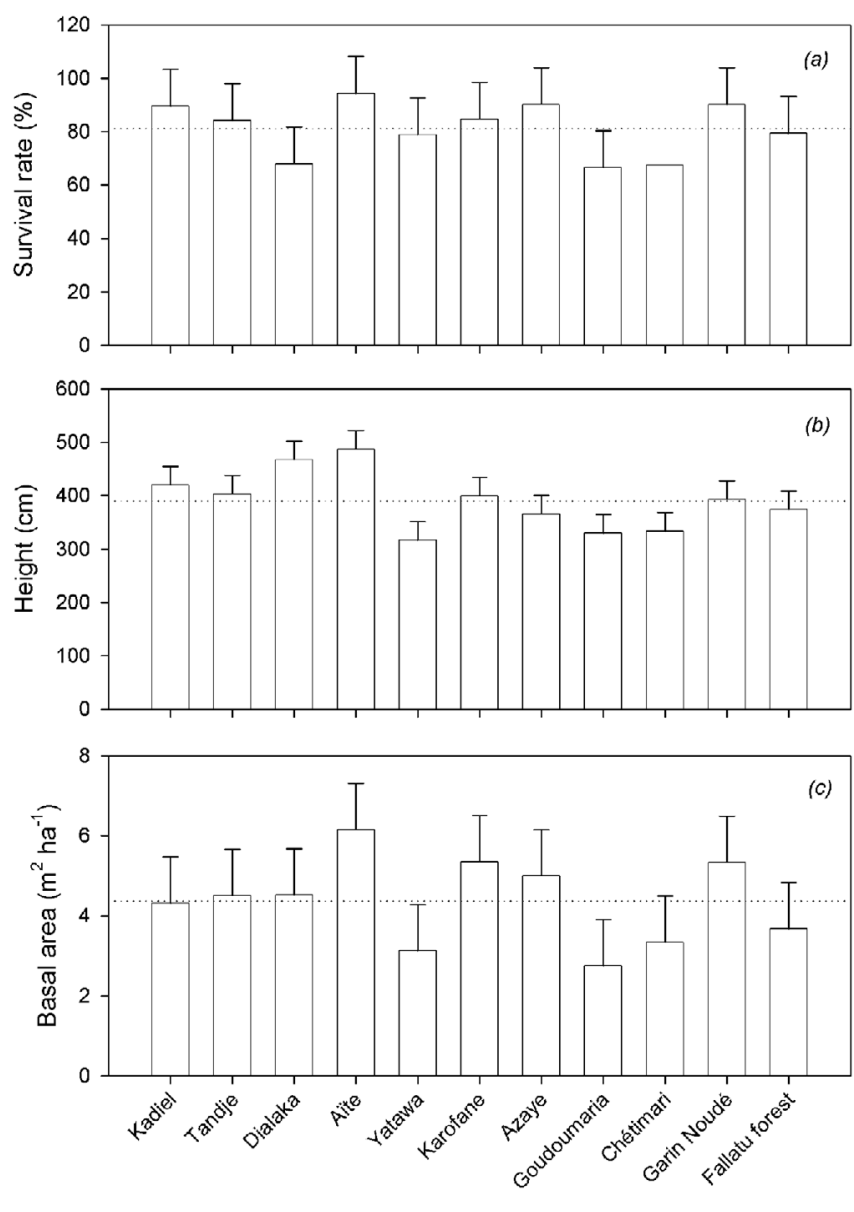

Provenance

Figure 1. - Least square means for growth parameters in provenances. Overall mean values are indicated by a dotted line. Error bars denote upper 95\% confidence intervals. $n=4$.

Variance components for provenance effects $\left(\sigma_{\text {prov }}^{2}\right)$ corresponding to model (1) were estimated from the expected mean squares and the coefficient of variation CVar $=\sigma_{\text {prov }} / \mathrm{X}$ (where $\mathrm{X}$ is the overall average across all provenances for the given trait) was calculated as a measure of the degree of genetic differentiation between the tested populations.

Correlations between growth parameters and gum, seed and fruit production on individual tree level were calculated using the Pearson correlation coefficients.

A multivariate analysis of provenance differences was performed based on the plot mean values of survival, height, basal area per tree, crown area per tree and the basal area per plot. The canonical variates were calcu- lated, and the standardised canonical scores were plotted against the first and second canonical variate. The approximate 2 dimensional 95\% confidence regions for the mean score were estimated as mean $\pm \frac{2}{\sqrt{n}}$, where $n$ is the number of replicates, in this case 4 (CHATFIELD and Collins, 1980).

Finally, a regression analysis was performed to examine the links between geographical origin and performance at the trial site at N'Dounga. Analyses were carried out using PROC REG (SAS ${ }^{\circledR}$ Institute Inc., Cary, $\mathrm{NC}$ ), and the least square means from univariate analyses as dependent variables. Independent variables were latitude, longitude, altitude, precipitation and a term comprising the squared value of precipitation. Before analyses, latitude and longitude were converted to decimal degrees. The square term was included to capture any optimum precipitation range. Variables were excluded using backwards elimination with a cutoff P-level of 0.10. Collinearity was checked using the variance inflation factor and the collinearity diagnostics (options VIF and COLLIN, SAS INsTituTE INC., 1989). There was important collinearity between longitude and altitude (variance inflation factors above 10), and it was decided to keep only the longitude in the model. However, in the interpretation it should be remembered that the effects of longitude and altitude cannot be separated. The verification of residuals showed that for the variable basal area, residuals increased with increasing predicted values, and the variable was transformed using the natural logarithm. This did not change the conclusions of the model, however, and for ease of interpretation it was decided to present results using the non-transformed data.

\section{Results}

The overall survival rate was $81 \%$ with significant differences between provenances and blocks (Table 3). One provenance from Mali (Aité) and two provenances from Niger (Azaye and Garin Noudé) had survival rates above $90 \%$. The provenances Goudoumaria and Chétimari from Niger and Dialaka from Mali had the lowest survival rates, below $70 \%$ (Fig. 1a). The least significant difference was $16 \%$. There were highly significant differences between blocks. However, differences between periodically inundated and non-inundated blocks were not significant and so must be attributed to other environmental parameters (Table 3 ).

With respect to height, the average was $390 \mathrm{~cm}$. However, there were significant differences between provenances, and the tallest were Dialaka and Aïté from Mali

Table 4. - Results of regression analyses for survival using backwards elimination. For results on height and basal area, see Fig. 2.

\begin{tabular}{lllll}
\hline Variable & Regression equation & $\mathbf{P}$ & $\mathbf{R}^{2}$ & $\mathbf{S E}$ \\
\hline Survival & $-1.01+0.0053(\mathrm{prec})-$ & Prec $=0.016$ & 0.81 & $\operatorname{Prec}=0.0017$ \\
& $0.0000056\left(\mathrm{prec}^{2}\right)+0.044(\mathrm{lat})$ & $\operatorname{Prec}^{2}=0.015$ & $\operatorname{Prec}^{2}=0.0000017$ \\
& Lat $=0.031$ & Lat $=0.016$ \\
\end{tabular}


with average heights reaching 467 and $484 \mathrm{~cm}$ respectively. The smallest provenances were Goudoumaria, Chétimari and Yatawa (all Niger), all having average heights less than $350 \mathrm{~cm}$ (Fig. 1b). The least significant difference was $50 \mathrm{~cm}$. There were significant differences between inundation zones. In blocks subject to periodical flooding, the adjusted average height was $428 \mathrm{~cm}$, whereas it was only $360 \mathrm{~cm}$ in blocks that were never inundated.

The average basal area was $4.4 \mathrm{~m}^{2} \mathrm{ha}^{-1}$, but with a large and significant variation between provenances. Aïte from Mali took the lead with $6.2 \mathrm{~m}^{2} \mathrm{ha}^{-1}$ followed by Garin Noudé and Karofane from Niger both with $5.3 \mathrm{~m}^{2}$ ha $^{-1}$ (Fig. 1c). Again, Goudoumaria, Chétimari and Yatawa from Niger were the smallest with basal areas of between 2.7 and $3.3 \mathrm{~m}^{2} \mathrm{ha}^{-1}$. The degree of genetic differences was thus large with a coefficient of variation of $20 \%$ for basal area per ha (Table 3). The least significant difference was $1.8 \mathrm{~m}^{2} \mathrm{ha}^{-1}$. The effect of inundation was highly significant, and the basal area in blocks exposed to periodical inundation was higher $\left(5.0 \mathrm{~m}^{2} \mathrm{ha}^{-1}\right)$ than in blocks that were not inundated $\left(3.9 \mathrm{~m}^{2} \mathrm{ha}^{-1}\right)$.

There were no significant differences between provenances in crown diameter, and the coefficient of variation was a modest $2 \%$. Block effects were not significant, and the effect of exposure to inundation was only at the limit of significance for this character.
The average gum production was $53 \mathrm{~g}$ tree ${ }^{-1}$, and the average fruit and seed production were 486 and $182 \mathrm{~g}_{\text {tree }}{ }^{-1}$, respectively. The tree-to-tree variation was very high for gum production with minimum value of $3.5 \mathrm{~g}$ and maximum value $295.5 \mathrm{~g}$ (standard deviation across all 87 assessed trees in all blocks was $58.3 \mathrm{~g}$ ). Neither of these traits proved significantly different between the provenances. Expressed on a single-tree basis, there were no significant correlations between these parameters and the other growth parameters (height, basal area and crown diameter), with the exception of the correlation between gum production and crown diameter which was at the limit of significance $(\mathrm{r}=0.21, \mathrm{p}=0.05)$. Based on this test we made another analysis of variance of provenance effects, in which we included the mean crown diameter of the trees assessed for gum production as a co-variable. The mean crown diameter again had a positive and almost significant effect on gum production $(\mathrm{P}=0.05)$, but still the provenance effect was far from significant (data not shown). Transforming data with the natural logarithm did not affect significance levels. As mentioned above, the variability between trees in gum production was high. In order to infer on the power of our test, we calculated the average within plot variation between trees in gum production (based on only 14 plots with 3 or more trees measured in the same plot) to $48.6^{2}$. Even with a balanced design of 3 trees assessed in each of three blocks this will correspond to an expected standard deviation
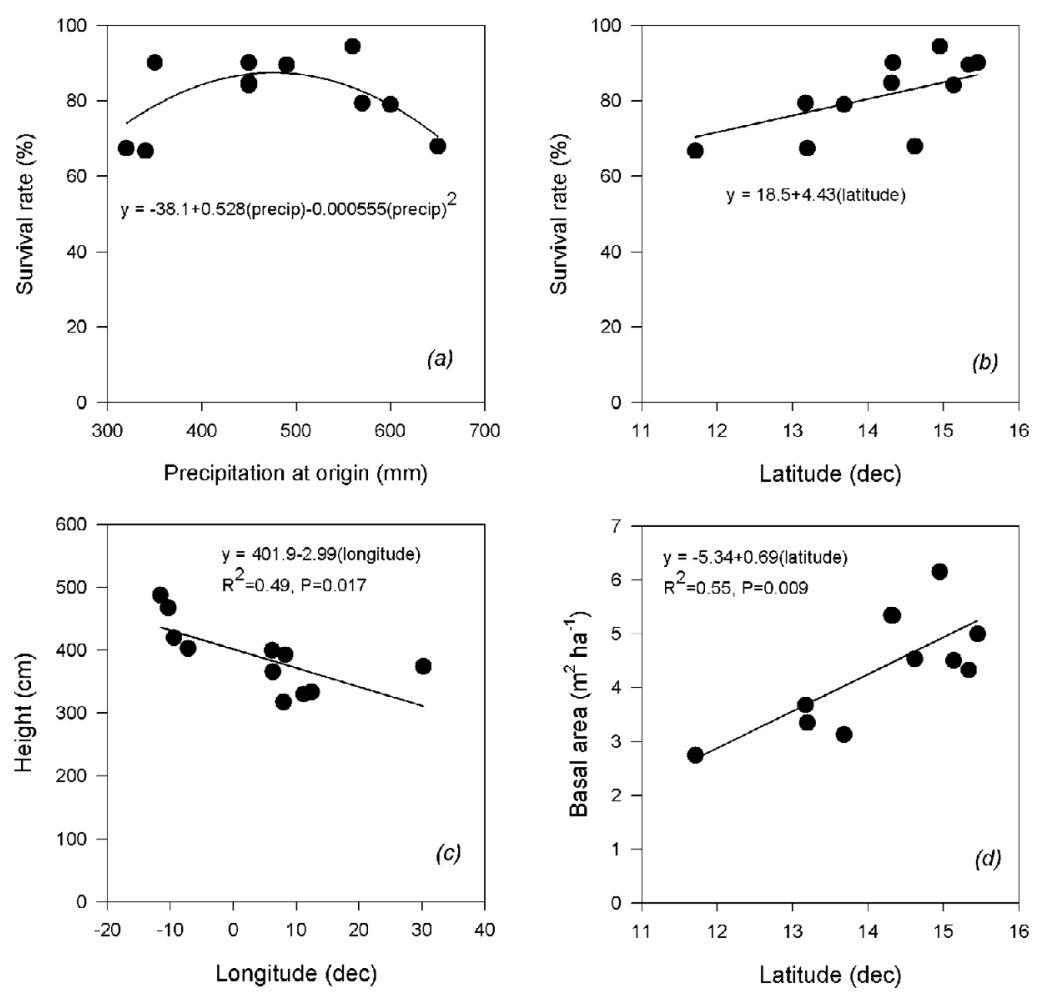

Figure 2. - Least square mean estimates for the provenances, plotted against precipitation, latitude and longitude at the origin (see text). Regression lines for survival are based on the equation in Table 4. For regression lines in (a), the average latitude for the provenances was used, whereas for (b), the average precipitation and the average squared precipitation were used. 


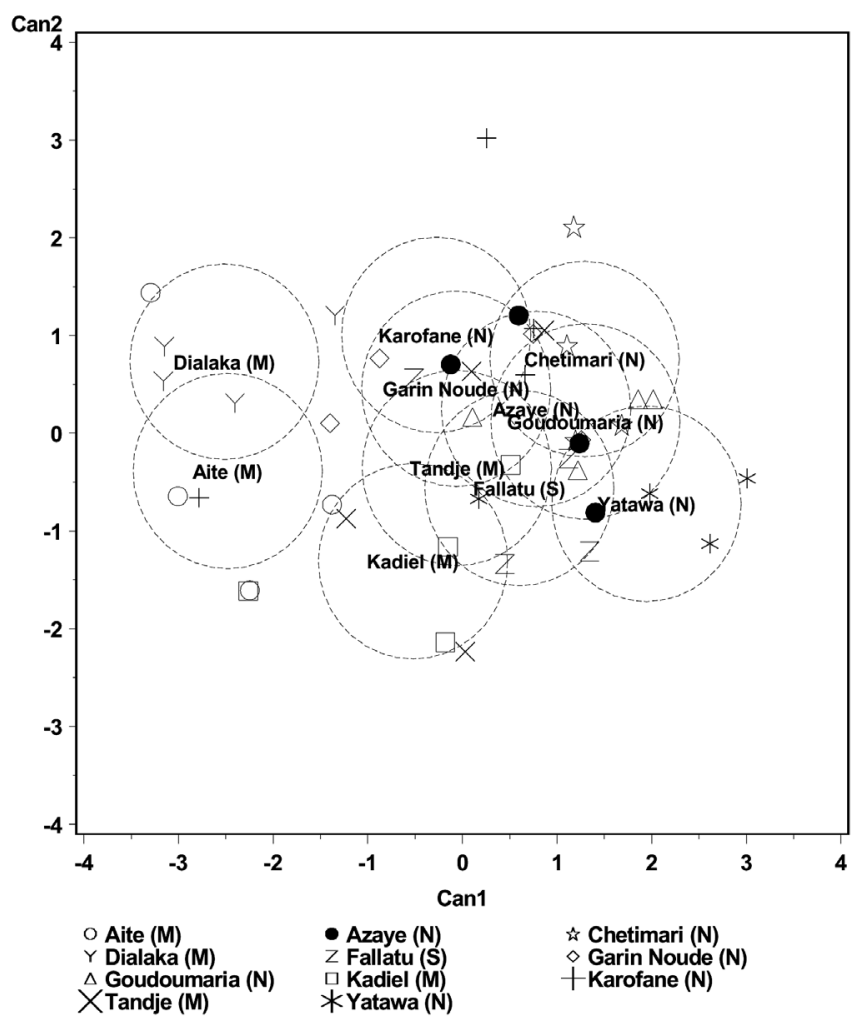

Figure 3. - Canonical scores of the provenances, plotted against the two first canonical variates. Mean values are surrounded by approximate $95 \%$ confidence regions. Letters in parenthesis indicate whether the provenances are from Mali, Niger or Sudan, respectively.

on the provenance mean of $\sigma($ Prov mean $)=48.6 /(\sqrt{ } 3 \sqrt{ } 3)$ $=16 \mathrm{~g}$. Given an average gum production of $53 \mathrm{~g}$ per tree, this result tells us that the applied design would only have been able to detect very large provenance effects with differences in magnitude of above $100 \%$. A more intense sampling based on 16 trees per plot could be expected to provided a more precise provenance estimate $\sigma($ Prov mean $)=48.6 /(\sqrt{ } 16 \sqrt{ } 3)=7 \mathrm{~g}$, but even this would be a moderate precision given the average production of $53 \mathrm{~g}$.

\section{Geographic patterns}

Results from the regression between conditions at the seed source origin and performance at N'Dounga are presented in Table 4 and Fig. 2. Survival was significantly correlated to the squared precipitation values (precip2), being higher for provenances with precipitation at the origins between 400 and $500 \mathrm{~mm}$. Latitude was also significant, Northern provenances having larger survival than Southern (Fig. 2(a) and 2(b)).

Height was significantly correlated to the longitude, Western provenances having faster growth than Eastern (Fig. 2(c)). It should be remembered, however, that longitude and altitude showed a high degree of collinearity, and in stead of an East-West gradient the correlation may express differences between low and high altitude provenances.

Basal area was correlated to the latitude, Northern provenances having faster growth than Southern (Fig. $2(d)$ ). This could be a reflection of the better survival, since when basal area was expressed per tree there was no correlation (data not shown).

Because the provenance from Fallatu, Sudan, had origin far from the group of West African provenances, it could be hypothesised that this provenance was driving the correlations. This was tested by eliminating the Fallatu provenance from the data and running the analyses again. For height, the effect of longitude became more significant $(\mathrm{P}=0.001)$. For the other variables, however, there were only small changes in correlation coefficients and significance levels (data not shown).

The multivariate analysis confirmed the highly significant differences between provenances. Only the first canonical variate was significant $(\mathrm{P}=0.0006)$ and explaining $62 \%$ of the variation, indicating that the variation was essentially in one dimension. Therefore, variation between provenances in Fig. 3 should be interpreted only against the first canonical variate. The standardized canonical coefficients indicate that variation along this variate was primarily caused by differences in height, with only minor contributions from survival and basal area.

The two Western-most provenances from Mali (Aïté and Dialaka) were placed towards the left side of the diagram, with the Eastern provenances from Niger and Sudan in the centre and to the right side. Removing the provenance Fallatu from Sudan produced only small changes in the rest of the picture (not shown). The multivariate analysis thus supported the picture from the univariate growth data of differentiation between an Eastern and Western group.

\section{Discussion}

Production of gum arabic is the most important commercial product from Acacia senegal. The available evidence points to water stress as one of the triggering factors for gum production (FAGG and Allison, 2004), and as provenances have different growth performance in the trial it could be expected that there would also be differences in gum production. Yet, it seems that despite a large variation in gum production between individual trees, it was not possible to identify significant differences between the tested provenances in the present trial. Gum yield was a moderate $53 \mathrm{~g}_{\text {tree }}{ }^{-1}$. We found no significant differences between provenances, but considerations regarding the expected power of the analysis showed that the applied design can only be expected to reveal very large differences because of the high tree to tree variation combined with the restricted sample size applied for assessment of the gum production. Previously, a substantially higher gum production was recorded in the trials (an overall mean production of $130 \mathrm{~g}$ tree $^{-1}$ varying between 90 and $188 \mathrm{~g} \mathrm{tree}^{-1}$ for individual provenances), but these data report only mean values and it is not clear whether differences between provenances were significant (unpublished data).

In a trial from Burkina Faso, differences between gum productions of African provenances were significant, but only in one of the two studied years (OUEDRAOGO, 2001). 
Furthermore, gum production per tree was very low in this trial, averages varying between 2 and $7 \mathrm{~g} \mathrm{tree}^{-1}$ for the provenances thus not reflecting realistic levels for commercial harvest. In another trial from Burkina Faso it was found that a landrace from India had significantly lower production than tested provenances from Africa (B.O. DiALlO, pers.com.). However, the provenance from India also had a very poor growth, and no significant differences were found between the African provenances. Also, in a trial with Sudanian provenances, RADDAD and LUUKKANEN (2006) found no significant differences in gum production. In the present trial comprising only African provenances measured in one year, differences between provenances were not significant. Besides the limitations due to the restricted sample size compared to the tree-to-tree variability, it shall also be noted that variation from year to year can be substantial. In a study of gum production at four sites in Burkina Faso, measured through four years, LoMPo (pers. com.) thus found large variations between years. Correlations between gum productions for individual trees in different years were small, and LOMPO propose that in genetic breeding programmes, gum production should be measured in several consecutive years in order to get a better estimate for the gum production potential of the provenance. However, whether this will result in significant differences between provenances is not sure, and the genotype $x$ environment interaction is also not known. Conclusive studies on variation in gum production between provenances are thus still lacking. The often applied procedure - to measure gum production on a limited subset of the trees in the trials in order to save time - seems not to be advisable. Our results indicate large tree to tree variation in gum production resulting in low power and precision in comparisons between provenances in gum production unless these are based on a number of trees comparable to what is required to prove significant differences in growth and adaptation. On very uniform test sites this may be different.

The large differences observed in growth and survival is in concordance with results from other studies. Considering adaptive characters several studies have thus found significant differences between provenances. Provenances from Asia have been found to have a poor performance in Burkina Faso (RAEBILD et al., 2003a,d; OUEDRAOGO, 2001), and provenances from Senegal had a good performance in a trial in India (RAEBILD et al., $2003 \mathrm{~b})$. A priori it therefore seems relevant to look at African provenances for the best performance. At the relatively old age of 15 years, the trial at N'Dounga is a unique possibility for assessing the adaptability of the species over a long time-span.

None of the provenances are local, since the closest provenance origin is approximately $400 \mathrm{~km}$ from the trial. However, they represent a wide range in precipitation and as such are a good sample of the population. The provenance with the best survival, height growth and basal area was Aite from Mali, but the provenances Garin Noudé, Karofane and Azaye had good performance too. Interestingly, the four provenances from Mali had the fastest height growth. Comparison with other West African trials is difficult as only few prove- nances are repeated across comparable trials and even the countries of origin represented in the comparable trials are often different. Therefore, it may be different provenances that are identified as superior in different trials. In three trials in Burkina Faso, for example, the best provenances with regards to basal area per ha were found to originate from Niger (RAEBILD et al., 2003a), Sudan (RAEBILD et al., 2003c) and Burkina Faso (RAEBILD et al., 2003d), respectively. Still, the mere finding that provenances vary substantially is important as it indicates that seed sources seem genetically differentiated and a careful genetic management therefore is advisable. In the present trial we thus found the fastest growing provenance to have a basal area per ha of two times the basal area of the slowest growing, and the differences are therefore of clear importance both in relation to seed procurement and domestication, but also in relation to genetic management and conservation effort.

Regression analysis indicated a link between geographic clines and performance. Our a priori hypothesis was that the fit between precipitation at origin and the trial site would be determinant for the performance of the provenances. This proved to fit in the case of survival, where the significance of the square term of precipitation indicated that there is an optimal level for precipitation, and that provenances from regions with precipitation deviating from this optimal level will have poorer survival. The optimal value of the fitted curve is close to the annual precipitation at the trial site, supporting a hypothesis of local adaptation. However, for growth variables latitude and longitude/altitude seemed more important. Whether this clinal variation is due to adaptation, introduction history or other factors is difficult to evaluate. The picture from the multivariate analyses shows that there are no clear patterns that can explain the differentiation. Provenances are placed relatively close together in the multivariate space, despite large distances geographically. The lack of correlation between geographical proximity and differentiation in growth traits is also in correspondence with results in Burkina Faso, where provenances also did not group according to simple geographical patterns (RAEBILD et al., 2003a,c,d). A particular striking example is the large variation between provenances from Senegal observed in the trial at Gonsé in Burkina Faso (RAEBILD et al., 2003d). Therefore, as long as no simple relation between performance and other factors has been found, there is no alternative to local testing if the best material is to be found.

Even with the above reservations, we find it interesting that the present trial points towards an East-West differentiation with Mali provenances growing more vigorously than Niger provenances. WEBER et al. (2008) also found a significant East-West cline for West African Prosopis africana (Guill. Et Perr.) Taub. provenances grown at a similar site in Niger, but for this species the slope of the cline was opposite with Eastern provenances performing better than Western. Prosopis africana in general grows on sites with higher precipitation compared to the natural distribution area of Acacia senegal, but it is of course highly speculative whether this can be part of the explanation of the inverse trend. 
More studies of genetic differentiation of native tree species across Subsaharian West Africa are in progress through the Sahelian Fruit Trees project (SAFRUIT), and it will be interesting to see if these confirm differentiation in eastern and western groups.

\section{Acknowledgements}

We thank technicians of INRAN for help in collecting the data for this article, and the three guards at N'Dounga station for taking care of the trial. We wish to thank an anonymous reviewer for constructive comments on an earlier version of the manuscript. The trial was established by INRAN with support from the IDA Project. Travel expenses of Mahamane Larwanou were covered by the performance contract between DANIDA and University of Copenhagen.

\section{References}

ARBonnier, M. (2002): Arbres, arbustes et lianes des zones sèches d'Afrique de l'Ouest. $2^{\text {nd }}$ edition, CIRAD, France, 573p.

Chatfield, C. and A. J. Collins (1980) : Introduction to multivariate analysis. Chapman \& Hall, London, 246 pp.

Cossalter, C. (1991): Acacia senegal: gum tree with promise for agroforestry. NTF highlights, NTFA 91-02: $1-2$.

FAGG, C. W. and G. E. Allison (2004): Acacia senegal and the gum Arabic trade. Tropical Forestry Papers 42, Oxford.

Larwanou, M., M. SAadou and A. Nonguierma (2005): Détermination du degré d'aridité bioclimatique de sept localités du Département de Tillabéri (sud-ouest du Niger): Classement en zones bioclimatiques. Sécheresse 16: 1-8.

National Academy of Sciences (1983): Firewood crops; shrub and tree species for energy production. Report of an Ad Hoc Panel of the Advisory Committee on Technology Innovation, Board on Science and Technology for International Development, Commission on International Relations. BOSTID Reports (USA), no. 27.
OuEDRAOGO, M. (2001): Analyse statistique dans le cadre de l'amelioration génétique forestière en zone soudanosahelienne: Cas d'un essai de provenances d'Acacia senegal. Faculté Universitaire des Sciences agronomiques de Gembloux, Gembloux.

RADDAD, E. Y. and O. LUUKKANEN (2006): Adaptive genetic variation in water-use efficiency and gum yield in Acacia senegal provenances grown on clay soil in the Blue Nile region, Sudan. Forest Ecology and Management 226: 219-229.

Raebild, A., B. O. Diallo, L. Graudal, M. Dao, M. and J. SANOU (2003a): Evaluation of a provenance trial of Acacia senegal at Djibo, Burkina Faso. Trial no. 5 in the Arid Zone Series. DFSC Results and Documentation 7, Danida Forest Seed Centre, Denmark.

Raebild, A., L. Graudal and K. M. Gammanagatti (2003b): Evaluation of a species and provenance trial of Acacia at B. G. Kere, India. Trial no. 15 in the Arid Zone Series. DFSC Results and Documentation 33, Danida Forest Seed Centre, Denmark.

Raebild, A., L. Graudal and G. L. Ouedraogo (2003c): Evaluation of a provenance trial of Acacia senegal at Dori, Burkina Faso. Trial no. 8 in the Arid Zone Series. DFSC Results and Documentation 3, Danida Forest Seed Centre, Denmark.

Raebild, A, L. Graudal and G. L. Ouedraogo (2003d): Evaluation of a provenance trial of Acacia senegal at Gonsé, Burkina Faso. Trial no. 12 in the Arid Zone Series. DFSC Results and Documentation 5, Danida Forest Seed Centre, Denmark.

Republique DU Niger (2003): Strategie nationale de relance de la production et de la commercialisation de la gomme arabique au Niger. FAO, Rome.

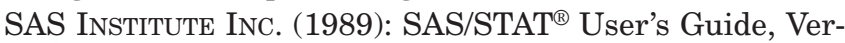
sion $6.4^{\text {th }}$ ed., vol. 2. SAS Institute Inc., Cary, NC.

von MAYDELL, H.-J. (1986): Trees and shrubs of the Sahel. GTZ, Eschborn, Germany.

Wickens, G. E., A. G. Seif Eldin, S. Guinko, S. and I. NAHAL (1995): Role of Acacia species in the rural economy of dry Africa and the near East. Forest resources division. FAO, Rome. 